\title{
Czynniki motywujące studentów do podjęcia studiów zagranicznych w ramach programu Erasmus+ oraz czynniki stanowiące dla nich bariery podczas pobytu za granicą na przykładzie studentów z Polski i Republiki Czeskiej
}

Streszczenie: W artykule podjęto rozważania dotyczące czynników, które motywują studentów przy podjęciu decyzji o wyjeździe zagranicznym w ramach programu wymiany Unii Europejskiej Erasmus+. Omówiono teoretycznie czynniki zarówno o podłożu poznawczym, takie jak: chęć poznawania kultury kraju przyjmującego, doskonalenie kompetencji językowych uczestników, możliwość podniesienia kompetencji zawodowych, czy też te o podłożu ekonomicznym, dotyczy to na przykład czynników związanych z kosztem utrzymania się w kraju wyjazdu. Grupę badaną stanowili polscy studenci wyjeżdżający w ramach programu Erasmus+ do czeskich uczelni oraz czescy studenci przyjeżdżający do uczelni znajdujących się w Polsce. Badaniami zostali objęci studenci kierunków pedagogicznych i filologicznych, studiujący w uczelniach czeskich oraz polskich. Przedmiotem przeprowadzonych badań były czynniki motywujące studentów do wyjazdu zagranicznego w ramach programu Erasmus+ oraz takie, które mogą stwarzać bariery i trudności podczas pobytu za granicą. Wyniki przeprowadzonych badań pozwalają zauważyć, że przy wyborze kraju goszczącego przez studentów największy udział mają nie czynniki motywacyjne o podłożu poznawczym, lecz czynniki ekonomiczne, takie jak, np. koszty utrzymania - ten aspekt wskazało najwięcej osób, jako najbardziej istotny przy wyborze miejsca wyjazdu. Można stwierdzić, że studenci wyjeżdżający na częściowe studia zagraniczne w ramach programu Erasmus+ kierują się najczęściej czynnikami o podłożu ekonomicznym, a więc sam wyjazd jest dla nich przede wszystkim czasem pewnej niezależności finansowej, a czynniki o podłożu poznawczym stanowią wartość dodaną mobilności. Optymizmem napawa fakt, że studenci w grupie badanej okazali się otwarci na poznawanie kultury kraju goszczącego.

Słowa kluczowe: motywy, bariery, Erasmus+, Polska, Republika Czeska, kompetencje międzykulturowe, studenci pedagogiki, studenci filologii 


\section{Wprowadzenie}

Podróż zagraniczna to zawsze stres dla jednostki, a długoterminowy wyjazd w celu podjęcia studiów (a w przypadku studentów uczestniczących w programie Erasmus+ może to być okres od jednego do dwóch semestrów) wiąże się z podwyższonym poziomem stresu oraz ryzykiem pojawienia się problemów o różnej etiologii, które mogą stać się poważnymi barierami zagrażającymi lub utrudniającymi funkcjonowanie jednostki w środowisku goszczącym. Dlaczego więc studenci decydują się na studia zagraniczne?

Nie budzi wątpliwości fakt, że w podjęciu decyzji o wyjeździe zagranicznym bardzo istotne są motywy, którymi kierowali się studenci aplikujący do programu Erasmus+. Joanna Wawrzyniak i Mariola Świderska (2011, s. 53-66) wskazują, że właśnie od siły i trwałości motywów w dużym stopniu zależy stosunek dorosłego ucznia do nauki oraz jego wytrwałość w uczeniu się, cierpliwość w pokonywaniu niepowodzeń i poziom poświęcenia się nauce.

Psychologowie wyróżniają obecnie następne podstawowe typy motywacji, istniejące w modelach teoretycznych wielu autorów (Doliński i Łukaszewski, 2002, s. 469-491), ale często występujących pod różnymi nazwami:

- motywacja hedonistyczna (przyjemnościowa), która charakteryzuje się dążeniem do przyjemności i eliminacji nieprzyjemności;

- motywacja epistemiczna (poznawcza), skierowana na poszukiwanie i zdobywanie informacji i wiedzy;

- motywacja do wywierania wpływu na to, co się wokół nas dzieje, spotykana również pod nazwą motywacji kompetencji lub własnej skuteczności).

Motywy, którymi kierują się kandydaci w programie Erasmus+, mają bezpośredni wpływ na dokonywany przez nich wybór kraju pobytu, a następnie uczelni zagranicznej. W taki sposób mogą one determinować przyszłe korzyści ze studiów za granicą. W pewnym stopniu motywy te studenci ujawniają $\mathrm{w}$ listach motywacyjnych, dołączanych do wniosku aplikacyjnego podczas procedury rekrutacyjnej. List ma celu przekonanie komisji, że to właśnie jego autor jest najlepszym kandydatem do otrzymania stypendium w danym kraju i w danej uczelni. Stanowi on jednocześnie jedyną i osobistą wypowiedź kandydata (z wyjątkiem, niekiedy, rozmów kwalifikacyjnych, które jednak nie są w żaden sposób utrwalane). Magdalena Sasin (2014, s. 80) na podstawie analizy kilkudziesięciu listów motywacyjnych kandydatów oraz źródeł inter- 
netowych (forów i blogów) w następujący sposób dostosowuje trzy powyższe typy motywacji do sytuacji studentów wyjeżdżających na studia zagraniczne:

a) hedonistyczną, która jest związana z chęcią rozrywki, zabawy, przeżycia przygody, nawiązywania niezobowiązujących kontaktów towarzyskich, a nawet seksualnych;

b) motywację wywierania wpływu, charakteryzującą się chęcią usamodzielnienia się, ucieczki spod skrzydeł rodziców, zasmakowania życia na własny rachunek, ale także z chęcią promowania polskiej kultury wśród rówieśników $\mathrm{z}$ innych krajów i funkcjonowania w roli jej przedstawiciela;

c) epistemiczną, która jest związana z chęcią poznania i z kolei dzieli się na cztery typy:

- motywacja epistemiczna w zakresie kierunku studiów, związana z chęcią doskonalenia wiedzy i umiejętności z zakresu studiów, poznania literatury naukowej niedostępnej w Polsce, zbierania materiałów lub przeprowadzenia badań do pracy dyplomowej (licencjackiej czy magisterskiej);

- motywacja epistemiczna w zakresie nauki języka obcego, czyli chęć doskonalenia umiejętności posługiwania się językiem obcym w naturalnym środowisku;

- motywacja epistemiczna w zakresie przyszłej pracy zawodowej, charakteryzująca się chęcią zdobycia doświadczenia, które w przyszłości pozwoli ułatwić znalezienie satysfakcjonującej pracy;

- motywacja epistemiczna w zakresie innej kultury, związana z chęcią poznania obcego kraju zarówno od strony kulturowej (zwyczaje, mentalność mieszkańców), geograficzno-historycznej (przyroda, zabytki), jak i edukacyjnej (warunki studiowania, system edukacyjny).

Autorka zauważa współwystępowanie poszczególnych typów motywacji, ale podkreśla, że jeden z nich zawsze jest dominujący. Zgodnie założeniami Programu, którego jednym z głównych celów jest podniesienie poziomu edukacji w UE, wydaje się, że osoby zarządzające programem Erasmus z góry zakładają, że jego uczestnicy powinni kierować się motywacją poznawczą, jednak doświadczenia wskazują, że niektórymi „erasmusami” kieruje motywacja hedonistyczna, a czasami także, w mniejszym stopniu, motywacja wywierania wpływu (na przykład uniezależnienie się od rodziców, samodecydowanie o sobie, radzenie sobie w obcym środowisku). Natomiast motywacja poznawcza najczęściej dotyczy poznawania obcej kultury i jej specyfiki, poszerzania wiedzy z zakresu kierunku studiów zaś - znacznie rzadziej (Sasin, 2014, s. 80-81). 
Chcąc potwierdzić powyższe wnioski, jeden z uczestników Programu - polski student, wypowiada się następująco: „Nie uczyliśmy się. Całe dnie leżeliśmy na plaży. Pieniądze z Unii Europejskiej wydawaliśmy na alkohol i marihuanę" (Machowski, 2013). Kontynuuje: „Międzynarodowe towarzystwo na Reunion zgrało się wyjątkowo szybko. [...] Nikomu z nas nie zdarzyło się jeszcze poznać tylu nowych ludzi, z tylu różnych miejsc, w tak krótkim czasie. Czuliśmy się, jak na niekończącej się wycieczce szkolnej” (Machowski, 2013). A czy nie potrzeba rozwoju kompetencji miękkich młodzieży i szerzej - obywateli UE, była podstawową przyczyną założenia Programu w latach 80. ubiegłego wieku? „Celem Unii - podkreśla Anne van Gemert z Biura Informacyjnego Parlamentu Europejskiego we Francji - jest promowanie wśród Europejczyków pewnych wartości, takich jak: solidarność, wolność, mobilność... w latach 80. XX wieku spostrzegliśmy się, że to, co sprawdziło się w gospodarce czy w rolnictwie, nie przyniosło rezultatów w obszarze cnót obywatelskich. Dlatego ruszył Erasmus" (Floc'h, 2009). Rozwijając tę myśl, Sara Pini z Fundacji na rzecz Innowacji Politycznej (Fondation pour l'innovation politique - Fondapol), była studentka Erasmusa stwierdza: „....wielokulturowe wspólnoty stają się „czymś w rodzaju domu, nadzwyczajną okazją praktycznego uczenia się Europy” (Floc'h, 2009).

Powyższe rozważania to cytaty ze sprawozdań końcowych, autorstwa studentów zagranicznych przebywających na czeskich uczelniach w ramach programu Erasmus z lat 1998-2007. Ich analiza wskazuje, że najsilniejszym czynnikiem motywującym studentów do studiowania za granicą jest „zdobywanie doświadczenia”. Wskazało na to ponad 70\% studentów. Również częstymi motywami do podjęcia nauki za granicą była możliwość poznania środowiska społecznego i kulturowego kraju goszczącego - ten czynnik motywuje około 40\% studentów, więcej niż jedna trzecia wszystkich studentów wskazała również jako motyw, możliwość zwiększenia swojej atrakcyjności na rynku pracy. Naukę języka obcego - jako motyw wyjazdu - wskazało 14\% studentów zagranicznych (Národní agentura pro evropské vzdělávací programy, 2007).

Pomimo tych pozytywnie nacechowanych motywów, które są katalizatorami zachęcającymi studentów do realizacji wyjazdu zagranicznego, towarzyszyć im mogą również różnorodne bariery (psychiczno-społeczne, formalnoprawne, językowe etc.) i to zarówno przed wyjazdem, jak i w trakcie pobytu za granicą.

K. Patricia Cross w 1981 roku wydzieliła trzy rodzaje barier (Smith, 1998), towarzyszących osobie dorosłej przy podjęciu decyzji o kontynuowaniu uczenia się, które można przeformułować i zastosować także do potrzeb określenia barier, z którymi zmagają się osoby wyjeżdżające na studia zagraniczne: 
1. bariery sytuacyjne (ang. situational barriers), które wynikają z bieżącej sytuacji jednostki w danym okresie, na przykład:

- niewystarczające zabezpieczenie finansowe,

- zatrudnienie w kraju pobytu,

- stan zdrowia,

- niekorzystna sytuacja rodzinna;

2. bariery instytucjonalne (ang. institutional barriers) - takie praktyki i procedury, które wykluczają lub zniechęcają dorosłych do uczestniczenia w działaniach, na przykład:

- niewystarczająca ilość informacji na temat możliwości studiowania za granicą,

- niezadowalająca oferta pobytów studyjnych (na przykład niska atrakcyjność oferowanych pobytów),

- problemy z uznawaniem zagranicznych studiów na uczelni macierzystej;

3. bariery osobowościowe (ang. dispositional barriers), dotyczące postaw i samopostrzegania siebie jako osoby uczącej się, na przykład:

- strach przed niepowodzeniem przy zakwalifikowaniu,

- strach przed brakiem umiejętności językowych,

- strach przed obcym środowiskiem i kulturą,

- zaniepokojenie trudnościami związanymi ze studiowaniem za granicą,

- strach przed przedłużeniem okresu studiów,

- strach przed przerwaniem więzi społecznych z krajem pochodzenia.

Przedstawiony model teoretyczny rozpatruje w etiologii barier oddziaływanie czynników sytuacyjnych, instytucjonalnych i dyspozycyjnych, które w dowolny sposób wzajemnie nakładają się na siebie i łączą się. Do tego dochodzi brak informacji. Jak zauważyła Veronica McGivney (1993, s. 17), powszechnym wnioskiem z badań uczestnictwa osób dorosłych w edukacji jest to, że osoby niebędące uczestnikami programów wymian edukacyjnych mają ograniczoną wiedzę lub w ogóle nie wiedzą o dostępnych możliwościach edukacyjnych.

\section{Metodologiczne podstawy badań własnych}

Przedmiotem przeprowadzonych badań (Dragomiletskii, 2018) były czynniki motywujące studentów do wyjazdu zagranicznego w ramach programu Erasmus+ oraz te, które mogą stwarzać bariery i trudności podczas pobytu za granicą. 
Grupę badaną stanowili polscy studenci wyjeżdżający w ramach programu Erasmus+ do czeskich uczelni oraz czescy studenci przyjeżdżający do uczelni polskich. Badaniami zostali objęci studenci kierunków pedagogicznych i filologicznych na uczelniach polskich (Uniwersytet Śląski w Katowicach, Uniwersytet Jagielloński) oraz czeskich (Uniwersytet Ostrawski, Uniwersytet Palackiego w Ołomuńcu).

W badaniach zastosowano metodę ankiety, której kwestionariusz składał się z pięciu części, w każdej części przedstawiono od 6 do 11 pytań, zarówno zamkniętych i otwartych. Dobór próby badanej wartościowy celowy. Badania przeprowadzono w maju 2018 roku;uzyskano odpowiedzi od 107 respondentów, z których 69 to studenci z polskich uczelni, a 38 z czeskich. Spośród respondentów przeważającą grupę stanowiły osoby w wieku 20-24 lata (71\%), natomiast około $25 \%$ to osoby w wieku $25-27$ oraz pojedyncze osoby w wieku od 28 do 38 lat. Większość osób, które wypełniły ankietę internetową, stanowią kobiety (73\%), a 27\% mężczyźni.

Jako metodę wspomagającą zastosowano obserwację etnograficzną (uczestniczącą) $)^{1}$ ukrytą, ponieważ zakłada ona zbieranie danych poprzez bezpośredni udział badacza w naturalnym środowisku społecznym (Rubacha, 2011, s. 151), a jako student przebywałem w ramach Programu Erasmus+ na uczelniach w Republice Czeskiej (Uniwersytet Ostrawski i Uniwersytet Palackiego w Ołomuńcu) i miałem okazję do bezpośredniej obserwacji życia zagranicznego studentów polskich uczelni.

\section{Czynniki motywujące studentów do wyjazdu zagranicz- nego oraz czynniki tworzące bariery studentom podczas pobytu w kraju goszczącym - wyniki badań}

Pierwsza część badań dotyczyła czynników charakteryzujących zagraniczny wyjazd studentów. Były to między innymi koszty utrzymania w kraju goszczącym w porównaniu do kosztów utrzymania w kraju ojczystym, odległość uczelni przyjmującej od miejsca zamieszkania studenta, oferta dydaktyczna uczelni przyjmującej oraz oferta rozrywkowa w miejscu pobytu, a także możliwość uczestniczenia w kursach językowych w trakcie pobytu zagranicznego,

1 Nazwy te są stosowane zamiennie w zależności od badacza. Na przykład Krzysztof Rubacha (Rubacha, 2011, s. 151) używa pojęcia „obserwacja etnograficzna”, a w pracach Mieczysława Łobockiego (Łobocki, 2011, s. 50) i Earla R. Babbie'go (Babbie, 2004, s. 331) spotkamy się z terminem „obserwacji uczestniczącej”. 
bezpośredniego kontaktu z językiem i kulturą kraju goszczącego oraz możliwość podniesienia atrakcyjności zawodowej na rynku pracy. Respondentów poproszono o wskazanie tych czynników, które odgrywały decydującą rolę przy wyborze kraju wyjazdu.

Ankietowanych poproszono o ocenę kosztów utrzymania w kraju wyjazdu i porównanie ich z kosztami w kraju zamieszkania. Połowa respondentów (z Polski i Czech razem) wskazała, że koszty utrzymania w kraju goszczącym są podobne do kosztów w ich kraju ojczystym, 27\% uważało, że są one wyższe, a 23\%, że niższe. Natomiast w odniesieniu do poszczególnych grup narodowościowych wyniki badań wyglądają następująco. Tylko $6 \%$ respondentów z Polski uważa, że koszty utrzymania w kraju pobytu były niższe, $55 \%$ wskazało na podobne koszty utrzymania, a 39\%, że były one wyższe. Zupełnie inaczej wyglądają odpowiedzi studentów z Czech - 54\% respondentów uważało, że koszty utrzymania w Polsce są zdecydowanie niższe, 41\% ocenia je jako podobne i tylko 5\% uważa, że życie w Polsce jest bardziej kosztowne niż w kraju rodzinnym. Wyniki te w pewnym stopniu potwierdzają powszechną opinię o „drogich Czechach" w świadomości Polaków, oraz o znacznie niższych cenach i kosztach utrzymania w Polsce. Potwierdzeniem tego są również przysłowiowe „tłumy” obywateli czeskich w supermarketach i centrach handlowych po stronie polskiej - zjawisko, które możemy obserwować na co dzień w miastach położonych w pobliżu granicy polsko-czeskiej, jak na przykład Cieszyn czy Bielsko-Biała.

Ważnym jest fakt, że większość badanych studentów razem (93\%) uważa, że bezpośredni kontakt z językiem i kulturą kraju goszczącego stanowi dla nich wartość samą w sobie. Zgadza się z tym 96\% Polaków i 89\% Czechów. Tylko $11 \%$ czeskich studentów i 3\% polskich (6\% z ogółu) miało wątpliwości co do takiego stwierdzenia, natomiast jeden student z Polski, zdecydowanie z nim się nie zgodził. Nieznaczne odchylenie w odpowiedziach w grupach narodowościowych może wskazywać na bardziej przychylne nastawienie Polaków wobec kultury czeskiej i większe zainteresowanie tą kulturą, i chociaż różnice nie są na tyle duże, aby móc wyciągnąć z tego jednoznaczne wnioski, tworzą jednak przyczynek do rozważań nad obrazem wzajemnych relacji polsko-czeskich.

93\% badanych studentów (91\% z Polski i 87\% z Czech) uczęszczało w kursach języka kraju przyjmującego w trakcie trwania wymiany zagranicznej, 66\% ankietowanych (64\% z Polski i 74\% z Czech) wskazało również na uczestnictwo w zajęciach z języka angielskiego, 30\% studentów z Polski i Czech (28\% z Polski i 34\% z Czech) skorzystało także z okazji uczenia się innych języków obcych. Natomiast jedna polska studentka wskazała, że nie miała żadnej z powyższych możliwości. 
Odnosząc się do stwierdzenia, że uczestnictwo w programie może stanowić wartość cenioną przez pracodawców, 79\% respondentów (77\% z Polski i 84\% z Czech) zgodziło się z tym, około $20 \%$ uczestników programu (22\% z Polski i 16\% z Czech) ma co do tego wątpliwości, a jedna polska studentka zdecydowanie nie zgodziła się z tą opinią.

Podczas pobytu zagranicznego w ramach studiów Erasmus+ ponad 77\% studentów miało możliwość uczęszczania na zajęcia z przedmiotów o pogłębionych treściach nauczania w ramach kierunku studiów, prawie $42 \%$ ankietowanych ukończyło dodatkowe kursy specjalistyczne, 9,5\% miało możliwość uzyskania certyfikatu potwierdzającego znajomość języka obcego; studenci mogli się także sprawdzić w działalności wolontariackiej (około 13\%), odbyć praktyki zawodowe (około 8\%) lub ukończyć kursy z zakresu rozwoju osobistego. Tylko około $14 \%$ respondentów odpowiedziało, że nie miało możliwości skorzystania z żadnej z tych ofert.

Wskazania studentów z badanych krajów dotyczące czasu oraz kosztów dojazdu z miejsca zamieszkania do uczelni przyjmującej były zróżnicowane. 71\% polskich studentów uważało, że czas dojazdu jest krótki, wśród czeskich wskazało na to $36 \%$ badanych. Wynik dla grupy badanej wynosi 59\%. Podobnie kształtowały się wyniki udzielonych odpowiedzi co do kosztów podróży. Dla 78\% studentów z Polski koszty te byłe stosunkowo niskie, ale zgodziło się z tym tylko 37\% studentów z kraju nad Wełtawą. Wynik dla grupy badanej wynosi $64 \%$. Można domniemywać, że różnice te mogą być spowodowane tym, że studenci z Polski najczęściej decydują się na wyjazd do uczelni usytuowanych w miastach w pobliżu granicy polsko-czeskiej i dobrze skomunikowanych z miejscem zamieszkania lub siedzibą uczelni macierzystej, takich jak na przykład Ostrawa lub Ołomuniec, a z kolei czescy studenci wybierają w Polsce duże ośrodki akademickie - Warszawę, Kraków lub Wrocław, znajdujące się w sporej odległości od granicy, jeśli nie geograficznie, to z pewnością o niezbyt dobrym skomunikowaniu. Być może przyczyna zróżnicowań w odpowiedziach tkwi również w tym, jak subiektywnie postrzegają odległość i czas podróży studenci w poszczególnych grupach, na przykład dla Czecha przyzwyczajonego do godzinnej podróży z Ostrawy do Ołomuńca siedmiogodzinna podróż pociągiem z Ostrawy do Warszawy rzeczywiście krótką nie jest.

Podczas pobytu w uczelni zagranicznej 35\% wszystkich badanych studentów uczestniczyło jedynie w zajęciach z przedmiotów zgodnych z ich kierunkiem studiów (30\% polskich studentów i 42\% czeskich), a 10\% uczęszczało przedmioty odpowiadające ich zainteresowaniom (10\% polskich studentów i $11 \%$ czeskich), lecz niekoniecznie zgodnych z profilem studiów, natomiast większość 
studentów (55\% ogółem, 59\% studentów z Polski i 47\% z Czech) miała możliwość uczęszczać zarówno na przedmioty bezpośrednio związane ze studiowanym kierunkiem, jak i na te, które dotyczyły ich osobistych zainteresowań.

88\% wszystkich respondentów (88\% w Polsce i 89\% w Czechach) wskazało, że aktywnie korzystało z oferty rozrywkowej w mieście pobytu, przy czym, jeśli z ofert restauracji, kawiarni, barów i klubów korzystało ponad trzy czwarte $\mathrm{z}$ nich, to takie atrakcje jak muzea, galerie sztuki, zabytki historii i architektury, miejskie festiwale i festyny czy nawet kino, interesowały tylko około dwóch czwartych respondentów. Do takich instytucji kultury, jak teatr czy opera udała się zaledwie jedna czwarta ankietowanych. 7\% studentów wskazało, że w ogóle nie korzystało z oferty rozrywkowej w miejscu pobytu, a $5 \%$ nie udzieliło odpowiedzi na to pytanie. Wyniki procentowe w poszczególnych grupach narodowościowych są zgodne z wynikami ogólnymi. Dane szczegółowe zostały przedstawione na wykresie 1.

Wykres 1. Rodzaje rozrywki wybierane najczęściej przez studentów podczas pobytu zagranicznego w ramach studiów Erasmus+

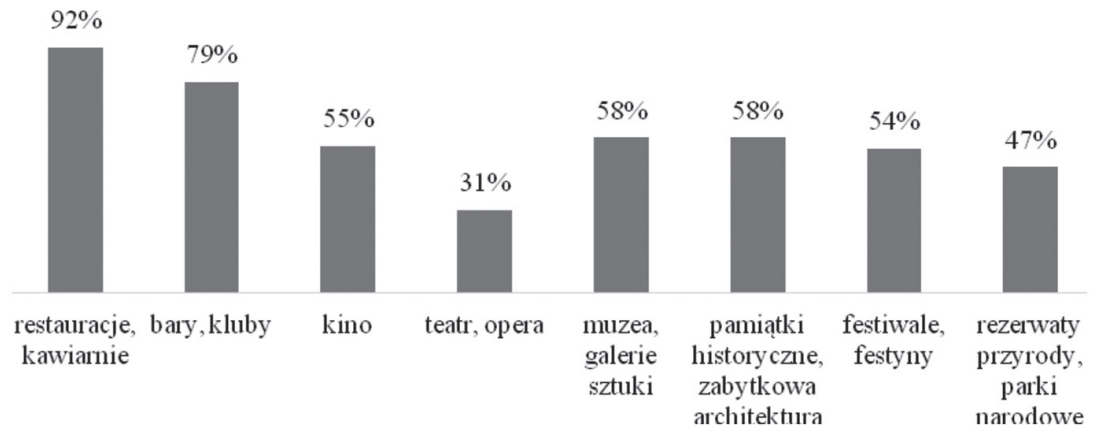

Źródło: opracowanie własne.

Legenda: dane nie sumują się do 100\%, ponieważ badani mogli wybrać więcej odpowiedzi.

Respondenci byli poproszeni również o uszeregowanie wszystkich czynników z powyższych pytań zgodnie z tym, który odgrywał najważniejszą rolę przy wyborze kraju wyjazdu, a który najmniej. Uzyskane wyniki zostały przedstawione na wykresie 2.

Z odpowiedzi polskich i czeskich studentów wnioskuje się, że dla większości z nich (34 osoby - 32\% z ogółu) czynnikiem decydującym o wyborze miejsca wyjazdu były koszty utrzymania w kraju goszczącym - tendencja ta zachowana 
jest również w poszczególnych grupach narodowościowych - 32\% (23 osoby) dla studentów polskich i 31\% (11 osób) dla studentów czeskich; bezpośredni kontakt z językiem i kulturą kraju przyjmującego był najważniejszym czynnikiem przy wyborze kraju wyjazdu dla 23 osób ogółem (15 osób - 22\% studenci polscy; 8 osób - 21\% studenci czescy), mniej ważna dla wszystkich studentów okazała się odległość uczelni przyjmującej od miejsca zamieszkania oraz jej oferta dydaktyczna wraz z ofertą rozrywkową w mieście pobytu.

Wykres 2. Czynniki decydujące o miejscu wyjazdu w opinii studentów

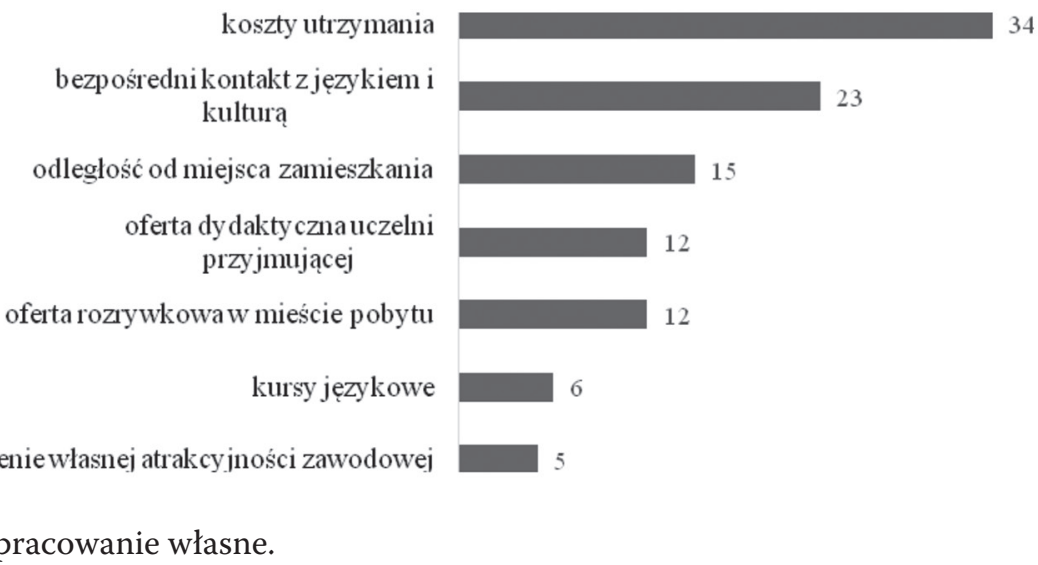

Możliwość uczęszczania na kursy językowe oraz podniesienie własnej atrakcyjności zawodowej w oczach przyszłych pracodawców okazały się najmniej ważnymi czynnikami ze wszystkich przy wyborze miejsca wyjazdu zarówno dla studentów z Polski, jak i z Republiki Czeskiej. Cztery osoby nie odpowiedziały na to pytanie.

Dane opisane powyżej pokazują, że o wybraniu przez studentów kraju wyjazdu zagranicznego nie decydują czynniki motywacyjne o podłożu poznawczym, takie jak na przykład chęć poznawania nowej kultury oraz rozwoju w zakresie kierunku studiów, ponieważ dla 32\% badanych studentów (zarówno z Polski i Czech) najważniejsze okazały się czynniki ekonomiczne, związane z kosztami utrzymania (czyli niskie koszty utrzymania) oraz z odległością wybranej uczelni od miejsca zamieszkania (czyli krótki czas i niski koszt dojazdu), chociaż czynniki poznawcze stanowią priorytet dla dużej grupy uczestników programu. Tendencja ta pozostaje zauważalna również w poszczególnych badanych grupach narodowościowych (Polska i Czechy), ale zarówno studenci polscy i czescy 
częściej wskazują jako czynnik motywujący możliwość poznania kultury kraju przyjmującego niż możliwość rozwoju w zakresie kierunku studiów.

\section{Czynniki stwarzające bariery dla studentów podczas wyjazdu}

Druga część badań dotyczyła czynników bezpośrednio związanych z procesem wyjazdu oraz takich, które w pewnym stopniu mogą stwarzać bariery dla studentów uczestniczących w wymianie zagranicznej.

Prawie połowa wszystkich studentów - 49\% wskazała na wystarczające zabezpieczenie finansowe podczas wyjazdu, które pozwoliło im również zaoszczędzić pewną kwotę na przyszłość. Wskazało na to $54 \%$ polskich studentów i 42\% czeskich. 35\% respondentów z ogółu wystarczyło na wszystkie potrzebne wydatki za granicą, lecz nie udało się niczego zaoszczędzić. Odpowiedziało tak 29\% studentów z Polski i 45\% z Republiki Czeskiej, natomiast 16\% studentów z ogółu musiało posiłkować się innymi źródłami finansowania (rodzina, praca, wcześniejsze oszczędności), ponieważ grant Erasmusa okazał się dla nich zbyt mały. Spotkało to $17 \%$ polskich studentów i 13\% czeskich.

Charakteryzując swój zasób wiedzy na temat kwestii formalnych, dotyczących uczestnictwa w programie Erasmus+, $62 \%$ wszystkich studentów oceniło go jako wysoki; dotyczy to 54\% Polaków i 76\% Czechów. 33\% respondentów z ogółu wskazało na luki w pewnych treściach (41\% studentów z Polski i 18\% z Czech) i tylko 5\% studentów oceniło swoją wiedzę jako niską (6\% Polaków i 5\% Czechów). Zgodnie z powyższymi danymi można wnioskować, że studenci czescy podchodzą z większym zaangażowaniem do zapoznania się z kwestiami formalnymi i regułami programu przed wyjazdem.

Najczęściej używanym językiem przez 49\% (49\%, 47\%) studentów w trakcie wymiany był język angielski, 29\% (33\%, 22\%) osób przeważnie używało języka kraju przyjmującego, a 22\% (16\%, 34\%) studentów podczas pobytu najczęściej posługiwało się językiem ojczystym.

Osoby, które w trakcie pobytu posługiwały się najczęściej językiem angielskim oceniły poziom swoich umiejętności językowych jako biegły. W przypadku $12 \%$ wszystkich badanych (15\% polskich studentów i $6 \%$ czeskich) zaawansowany poziom zadeklarowało $35 \%$ respondentów ogółem (39\% polskich studentów i $25 \%$ czeskich), a średniozaawansowany $51 \%$ ogółem (42\% polskich studentów i 69\% czeskich), i tylko $2 \%$ ze wszystkich studentów (3\% polskich i 0\% czeskich) oceniło swój poziom językowy jako początkujący. W przypadku studentów więcej używających w czasie wymiany języka kraju 
przyjmującego uzyskane wyniki wyglądają podobnie: $16 \%$ ogółem (13\% polskich studentów i $25 \%$ czeskich) - poziom biegły, $26 \%$ ogółem (26\% polskich studentów i $25 \%$ czeskich) - poziom zaawansowany, $48 \%$ ogółem (52\% polskich studentów i 38\% czeskich) - poziom średniozaawansowany i 10\% ogółem (9\% polskich studentów i 13\% czeskich) - poziom początkujący.

$32 \%$ studentów ogółem (27\% polskich studentów i 40\% czeskich) przyznało się do odczuwania strachu przed obcym środowiskiem i kulturą podczas pobytu zagranicznego, u 70\% z nich (69\% polskich studentów i 62\% czeskich) strach ten dotyczył kwestii nawiązywania relacji międzyludzkich zarówno w kontaktach formalnych, jak i nieformalnych, u 30\% (31\% polskich studentów i 38\% czeskich) odnosił się on do czynności codziennych, związanych z warunkami życia w akademiku lub norm i obyczajów charakterystycznych dla kraju przyjmującego. U 68\% respondentów podobne obawy nie występowały.

Wysoki poziom zadowolenia z wyników zaliczenia semestru (roku) wskazało $80 \%$ respondentów (76\% polskich studentów i 86\% czeskich), średni $20 \%$ studentów ( $24 \%$ polskich i $14 \%$ czeskich), niski poziom zadowolenia nie został wskazany przez żadnego ankietowanego, mimo że uczelnie macierzyste w przypadku pięciu osób (czterech z Polski i jednej z Czech) w ogóle nie uznały wyników uzyskanych podczas wyjazdu, u 10 osób (u siedmiu z Polski i trzech z Czech) wyniki zostały uznane częściowo, a dla 13 osób (dla siedmiu z Polski i sześciu z Czech) okres studiów został wydłużony o co najmniej semestr. Natomiast 92 osoby (86\% ogółem, $92 \%$ polskich studentów i 89\% czeskich) wskazały, że uzyskały pełne uznanie wyników z przedmiotów realizowanych podczas wymiany.

Na koniec badania studenci zostali poproszeni o wskazanie, które z czynników opisanych powyżej stanowiły dla nich problem lub barierę w trakcie pobytu za granica. Uzyskane odpowiedzi zostały przedstawione na wykresie 3.

Przedstawione wyniki wskazują, że czynnikiem, który sprawiał najwięcej kłopotów studentom podczas pobytu za granicą, jest czynnik bezpośrednio związany ze znajomością informacji formalnych dotyczących wymiany; rozumie się pod tym zarówno kwestie dotyczące prawidłowego wypełnienia niezbędnych dokumentów, jak i ogólnych zasad i wymogów uczestnictwa w programie. Ciekawym wydaje się fakt, że więcej kłopotów dany czynnik sprawiał studentom z Republiki Czeskiej (23\%) niż studentom z Polski (13\%), mimo że wcześniejsze odpowiedzi czeskich studentów wskazywały na bardziej zaawansowany poziom znajomości kwestii formalnych wyjazdu u nich niż u polskich studentów. 
Wykres 3. Czynniki stanowiące bariery dla studentów w trakcie pobytu zagranicznego w ramach programu Erasmus+

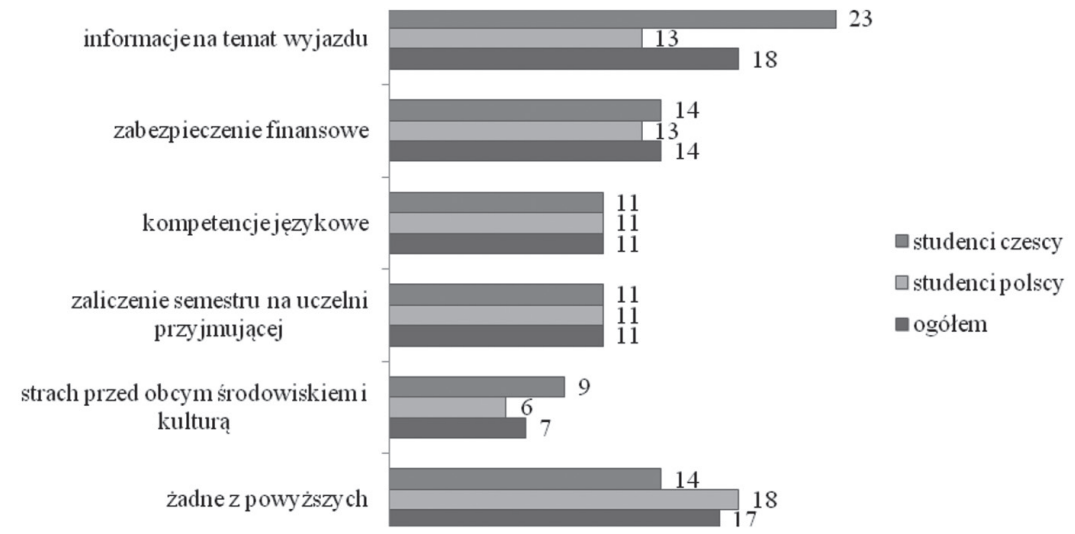

Źródło: opracowanie własne.

Legenda: częstotliwość wskazania poszczególnych czynników przez studentów w \%. Każdy respondent mógł zaznaczyć od 1 do 6 odpowiedzi.

Zabezpieczenie finansowe - czynnik, który znalazł się na drugim miejscu względem częstotliwości wyboru przez studentów. Nie wydaje się dziwnym to, że 53\% studentów spośród tych, którzy wybrali ten czynnik wcześniej, wskazywało na niewystarczające środki finansowe podczas pobytu, natomiast nie do końca jest zrozumiały fakt, że kolejne $37 \%$ studentów jest z grona tych, którzy w poprzednim pytaniu dotyczącym kwestii finansowych pobytu deklarowali, że nie odczuwali braku pieniędzy w trakcie wymiany, a następnym $11 \%$ nawet udało się zaoszczędzić pewną kwotę.

Czynniki związane z kompetencjami językowymi oraz kwestiami zaliczania semestru na uczelni przyjmującej znalazły się na trzecim miejscu. Najczęściej wybierały czynnik językowy osoby na średniozaawansowanym poziomie znajomości języka, który był używany przez nich za granicą. Chociaż znalazła się również jedna osoba, która ocenia swój poziom, jako biegły. Jeśli chodzi o osoby, które miały obawy co do zaliczenia semestru na uczelni goszczącej, to u żadnego z respondentów one się nie sprawdziły, a wszyscy byli zadowoleni z wyników końcowych semestru.

Studenci, którym sprawiał kłopot czynnik związany z poczuciem strachu przed obcym środowiskiem, wskazywali wcześniej na problemy z dostosowaniem się do realiów życiowych kraju przyjmującego lub na trudności w kontaktach międzyludzkich podczas pobytu. 


\section{Podsumowanie}

Wyniki przeprowadzonych badań pozwalają zauważyć, że przy wyborze kraju goszczącego przez studentów największy udział mają nie czynniki motywacyjne o podłożu poznawczym, lecz czynniki ekonomiczne, takie jak, na przykład koszty utrzymania - ten aspekt wskazało najwięcej osób, jako na najbardziej istotny przy wyborze miejsca wyjazdu.

$\mathrm{Na}$ drugim miejscu - według częstotliwości odpowiedzi - znalazł się czynnik wprost związany z chęcią bezpośredniego kontaktu z kulturą kraju przyjmującego. Na trzecim miejscu znalazła się kwestia odległości od miejsca zamieszkania. Oferta edukacyjna, na równi z ofertą rozrywkową, znalazła się na przedostatnim miejscu w rankingu istotności, a możliwość rozwijania kompetencji językowych okazały się najmniej ważna. Czynniki o podłożu poznawczym razem stanowią mniej niż połowę wszystkich czynników wskazanych przez studentów, co pokazuje, że jednak to nie one są najbardziej istotne w procesie podejmowania decyzji o wyborze miejsca (miasta) wymiany zagranicznej, niezależnie czy są to studenci polscy, czy czescy.

Prawie jedna trzecia studentów podczas wyjazdu zagranicznego napotykała bariery o charakterze osobowościowym, czyli związane z kompetencjami językowymi, odnalezieniem się w nowej kulturze oraz instytucjonalnym, związanym z brakiem informacji formalnoprawnych dotyczących wyjazdu - trzecia część respondentów w trakcie wyjazdu odczuwała strach przed obcym środowiskiem i kulturą, co prawda kłopoty z językiem miało niewiele studentów, a do niewystarczającej wiedzy w kwestiach formalnych dotyczących wyjazdu przyznało się zaledwie kilka zapytanych studentów, chociaż problemy w tym obszarze napotkała jedna czwarta wszystkich respondentów. Można stwierdzić, że studenci wyjeżdżający na częściowe studia zagraniczne w ramach programu Erasmus+ kierują się najczęściej czynnikami o podłożu ekonomicznym, a więc sam wyjazd jest dla nich przede wszystkim czasem pewnej niezależności finansowej, a czynniki o podłożu poznawczym stanowią wartość dodaną mobilności. Cieszy fakt, że czynnik związany z poznawaniem nowej kultury znalazł się na drugim miejscu - świadczy to o chęci poznawania Innego, nawet tego bliskiego, a to bardzo ważna kompetencja, szczególnie dla przyszłych nauczycieli. 


\section{Bibliografia}

Babbie, E. 2004. Badania spoteczne w praktyce. Warszawa: PWN.

Doliński, D. i Łukaszewski, W. 2002. Typy motywacji. W: Strelau, J. red. Psychologia. Podręcznik akademicki. T. II. Gdańsk: GWP.

Dragomiletskii, A. 2018. Strategie kulturalizacyjne studentów uczestniczacych w programie Erasmus+ - na przykładzie studentów z Polski i Czech. Praca magisterska przygotowana pod kierunkiem dr hab. B. Grabowskiej, prof. UŚ. Cieszyn: Uniwersytet Śląski, Wydział Etnologii i Nauk o Edukacji.

Floc'h, B. 2009. Erasmus - fabryka Europejczyków. VoxEurop. http://www. voxeurop.eu/pl/content/article/16171-erasmus-fabryka-europejczykow/ (17.04.2018). Wersja oryginalna artykułu: Floc'h, B. 2009. En vingt ans, le programme d'échange Erasmus a créé un esprit européen. Le Monde. http://www.lemonde.fr/europe/article/2009/06/01/en-vingt-ans-le-programme-d-echange-erasmus-a-cree-un-esprit-europeen_1200736_3214. html\#xUYRaQ8vr33MjsA6.99/ (17.04.2018).

Łobocki, M. 2011. Metody i techniki badań pedagogicznych. Kraków: Oficyna Wydawnicza „Impuls”.

Machowski, F. 2013. Na Erasmusie, czyli w raju. Gazeta Wyborcza. http:// wyborcza.pl/1,76842,13839852,Na_Erasmusie__czyli_w_raju.html/ (17.04.2018).

McGivney V. 1993. Women, Education and Training. Barriers to access, informal starting points and progression routes. Leicester: National Institute of Adult Continuing Education, Hillcroft College.

Národní agentura pro evropské vzdělávací programy. 2007. Erasmus v Česke republice 1998-2007. http://www.dzs.cz/cz/erasmus-plus/ (22.03.2018).

Rubacha, K. 2011. Metodologia badań nad edukacja. Warszawa: Oficyna Wydawnicza „Łośgraf”.

Sasin, M. 2014. Polscy studenci w programie wymiany międzynarodowej „Erasmus” - założenia, stan faktyczny i możliwości zmiany. Dyskursy Młodych Andragogów. 15, ss. 75-84.

Smith, M.K. 1998. Participation in learning projects and programmes. The encyclopaedia of informal education. http://infed.org/mobi/participation-in-lear ning-projects-and-programmes/ (19.03.2018).

Wawrzyniak, J.K. i Świderska, M.M. 2011. Motywacje edukacyjne uczniów dorosłych. W: Przygońska, E. red. Motywacja w edukacji. Toruń: Wydawnictwo Adam Marszałek. 


\title{
Factors motivating students to undertake studies abroad within the Erasmus+ programme and the barriers for them during their foreign visit - the case of students from Poland and the Czech Republic
}

\begin{abstract}
The article refers to the factors that motivate students when making a decision to travel abroad within the framework of the European Union exchange Program Erasmus+. The article theoretically considers the factors some cognitive, such as the desire to learn the culture of the host country, improving the language competence of participants, improving professional competence, as well as those related to economy, for example, factors related to the cost of living the country of departure. The study group consisted of Polish students travelling within the Erasmus+ Program to Czech universities and Czech students coming to the universities located in Poland. The research covered students of pedagogical and philological specialties studying in Czech and Polish universities. The subject of the research were the factors of motivation of students to travel abroad in the framework of the Erasmus + program, as well as those that can create barriers and difficulties during their stay abroad. The results of the research allow for noticing that when choosing the country of the guest students the largest share does not consist of cognitive factors, but economic factors, such as, for example, maintenance costs - this aspect is indicated by the biggest groupe as the most significant when choosing the place of departure. It can be concluded that students who travel for partial foreign studies under the Erasmus+ program are guided by the most common factors of the economic basis, and therefore the stay is for them, first of all, a time of some financial independence, and the factors of cognitive basis represent the added value of mobility. It is encouraging that the students in the group were open to study the culture of the host country.
\end{abstract}

Keywords: motives, barriers, students, Erasmus+, Poland, Czech Republic

Translated by Anton Dragomiletskii 